\title{
COMPULSORY MOTOR VEHICLE INSURANCE AND COURT CONGESTION IN MASSACHUSETTS
}

\author{
DUNBar F. CARPENTER*
}

There took effect in the Commonwealth of Massachusetts on January $x, x 927$, "An Act requiring owners of certain motor vehicles and trailers to furnish security for their civil liability on account of personal injuries caused by their motor vehicles and trailers." 1 This act, commonly known and hereinafter referred to as "the compulsory motor vehicle insurance act," provides that no motor vehicle or trailer privately owned shall be registered in the Commonwealth unless the application for régistration is accompanied by a certificate from an insurance company authorized to transact casualty business in the Commonwealth stating that it has issued to the applicant a policy to the amount of at least $\$ 5,000$ on account of injury to or death of any one person, and of at least $\$ 10,000$ on account of any one accident resulting in injury to or death of more than one person, arising out of the unlawful or negligent operation of a motor car upon the ways of the Commonwealth. ${ }^{2}$ The insurance policy actually covers the particular car insured, as it covers not merely the owner but also "any person responsible for the operation of the insured's motor vehicle with his express or implied consent. ..."3

Broadly speaking, therefore, any person injured, and the estate of any person killed, upon the public ways of the Commonwealth by the unlawful or negligent operation of a privately owned Massachusetts car are assured of the payment of any judgment that may be recovered up to $\$ 5,000$. If a judgment exceeds the $\$ 5,000$ or

- A.B., I900, LL.B., I903, Harvard University. Member of Massachusetts Bar, practising in Boston. Editor of Bar Bulletin published by the Bar Association of the City of Boston.

${ }^{1}$ Mass. Acts r925, c. 346 , MAss. GEN. LAws ('Tercent. ed. 1932) c. 9o, especially \$\$IA, 34A-34J.

2 There are alternative provisions, allowing an applicant for registration to give a surety bond or to deposit with a state department $\$ 5,000$ in cash, bonds or stock, in lieu of insurance, but these alternatives are seldom, if ever, used.

Motor vehicles owned by the Commonwealth or any political division are excepted, id. c. 9o, \$rA, as are also those owned by common carriers of passengers (railroads and street railways). The latter, however, are required to deposit with the state treasurer a surety bond to cover payment of final judgments for injury to person or property, or for death, arising out of any negligent or unlawful act in the use or operation of their motor vehicles. Id. c. $159 \mathrm{~A}$, \$6. Hence for all practical purposes railroads and strect railways operating motor vehicles may be considered as "insured."

${ }^{8}$ Id. c. $90, \$ 34 \mathrm{~A}$. In order to recover on the insurance policy, the action must be brought against the insured, whether or not he was operating the car at the time of the accident, within one year after the accident.

"The exceptions are (I) where the car is being operated without the consent of the owner, e.g., stolen; (2) where the insurance policy has been cancelled, e.g., for non-payment of the premium, and the 
$\$ r 0,000$ limit, the plaintiff can recover the excess from the insurer up to the amount of insurance above the statutory minimum which the insured may be carrying, or from the defendant, provided the latter has property which can be reached on execution.

The act prescribes that the premiums for coverage shall be fixed by the State Commissioner of Insurance. For this purpose the insurers conduct a bureau under the supervision of the State Insurance Department which collects, classifies, tabulates and analyzes the combined experience data of the insurers, submitting annually these data with recommendations for rates for the ensuing year to the Insurance Commissioner who has the sole duty of fixing fair and reasonable classifications of risks and adequate, just and non-discriminatory premiums.

It has seemed necessary to give in broad outlines a summary description of the compulsory motor vehicle insurance $\mathrm{act}^{6}$ before proceeding to discuss the narrow issues to which this article is confined, to wit: the effect of the act upon the courts, and the measures taken to increase the capacity of the judicial system.

\section{The Organization of the Massachusetts Judicial System}

The Supreme Judicial Court for the Commonwealth. The Supreme Judicial Court, consisting of a chief justice and six associate justices, is the appellate court, and as it manages to keep pretty well abreast of its work, although always under substantial pressure, it need not further concern us.

The Superior Court. The Superior Court, consisting of a chief justice and thirtyone associate justices, covers the state, holding sittings in every county, at times fixed by the chief justice, to which sittings the associate justices are assigned by the chief justice. The Superior Court tries all jury cases, both civil and criminal, and has general jurisdiction in equity.

The District Courts. There are seventy-two district courts scattered throughout the Commonwealth, exclusive of the Municipal Court of the City of Boston. The latter, although properly a part of the district court system, and hereinafter included when reference is made-to district courts unless otherwise indicated, is in fact an integrated court with a chief justice and eight associate justices. The other district courts are separate and distinct from each other. Each of these courts has a presiding justice who is paid a fixed salary dependent upon the population in his district, and one or more special justices who serve only when called upon by the presiding justice or in case of his disability. There are no juries in district courts.

registration plates have not been surrendered to the Registrar of Motor Vehicles as required by statute; and (3) where an insurer has become insolvent.

It is common for owners who are financially responsible to insure for $\$ 10,000 / \$ 20,000$, and even greater amounts.

- While it is not in any sense the purpose of this article either to oppose or defend the Massachusetts act, it is pertinent to the purposes for which it is written to remark that, although bills for the repeal of the act are submitted annually to the legislature, the compulsory insuring of motor cars appears to have become the settled policy of the Commonwealth. 
The district courts were originally police courts with extremely limited civil and criminal jurisdiction. Though their criminal jurisdiction is still somewhat limited, they now have unlimited civil jurisdiction of law cases, but none in equity. For a number of years prior to 1929, the civil jurisdiction of these courts was limited to cases involving less than $\$ 3,000$ (that of the Boston municipal court to $\$ 5,000$ ), but in 1929 the legislature removed the jurisdictional limits of all the district courts by giving them and the Boston municipal court original jurisdiction concurrent with the superior court of all actions of contract, tort and replevin, and of actions in summary process, regardless of the amount involved.

For present purposes, ${ }^{7}$ we have two systems of courts, both having concurrent original jurisdiction of law actions. The superior court, with thirty-two judges, sitting throughout the state, is the sole jury court. The other court consists of seventy-two independent district court judges, nine Boston municipal court judges and more than one hundred and fifty special judges, each district court having one or more such special judges, and the Boston municipal court, six.

It is well to keep in mind the disparity in man-power, or better perhaps judgepower, between the two courts-the superior court with its thirty-two justices, and the district courts with somewhat more than two hundred and thirty justices-for presumably two hundred and thirty judges, sitting without juries, can try very many more cases than thirty-two judges, especially when the latter sit frequently with juries. An offset to the foregoing presumption is that, owing to historical reasons, many of the district courts are in small towns and handle few, if any, civil cases.

\section{Effect of Compulsory Motor Vehicle Insurance on Litigation}

Crvil. Cases Entered in Superjor Court

\begin{tabular}{|c|c|c|}
\hline & & \\
\hline Year Ending & Law & Equity \\
\hline June 30 , rgro... & 10,868 & I,599 \\
\hline June $30,1920 \ldots \ldots \ldots \ldots \ldots$ & 15,638 & 2,208 \\
\hline 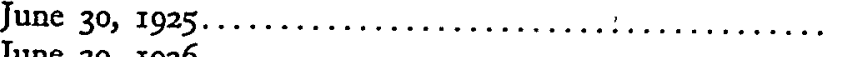 & 23,090 & 3,009 \\
\hline 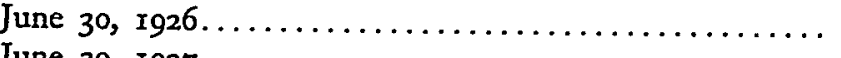 & 23,223 & 3,316 \\
\hline 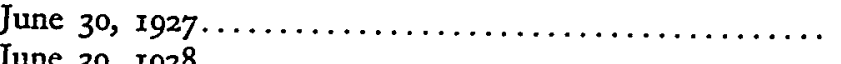 & 24,513 & 3,655 \\
\hline 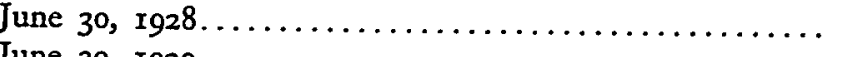 & 32,633 & 3,392 \\
\hline 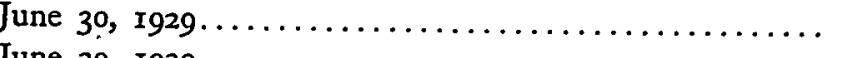 & 33,335 & 3,502 \\
\hline 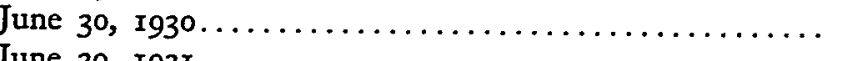 & 35,190 & 3,642 \\
\hline 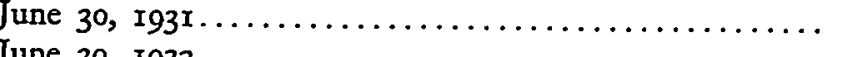 & 36,190 & 3,604 \\
\hline 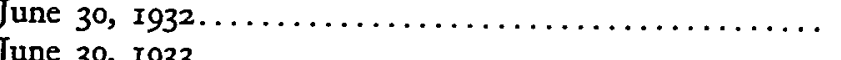 & 34,464 & $3,4 I I$ \\
\hline 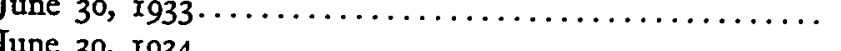 & 28,587 & 3,536 \\
\hline 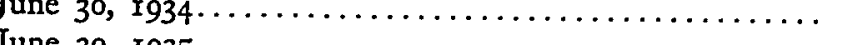 & 25,446 & $3,25 x$ \\
\hline 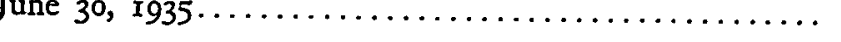 & 22,075 & $2,88 \mathrm{I}$ \\
\hline
\end{tabular}

It will be observed from the foregoing table that from Igro up to June 30,1927 the increase in law entries, although more than doubling, conformed fairly closely to the increase in equity entries. The compulsory motor vehicle insurance act took

${ }^{2}$ Other courts such as the land courts and the probate courts have no relation to this subject. 
effect on January $I$, I927. Its results clearly appear in the number of entries for the court year beginning July I, I927 and ending June 30, I928, which show an increase of over 9,000 entries above those for the year ending June 30, 1926, the last full court year prior to the effective date of the act. While it cannot be positively asserted that the increase in entries was composed solely of motor tort cases, there being no separate statistics on that point, nevertheless, it seems obvious that such was the fact. The Massachusetts Judicial Council stated in its 1929 report $^{8}$ that for the five months' period from October I, 1927 to March I, I928 there were 4,20I more law cases entered in the superior court than in the same period October 1926 to March 1927, and that of this increase 97.4 per cent were motor vehicle cases.

It is hardly necessary to draw attention to the sharp decline in law entries beginning after June 30, I93x, the entries for the year ending June 30, 1935 being 14,000 less than for the peak year, 1931, and approximately on a level with the entries for I925. A possible explanation therefor is the depression, although while law entries decreased 39 per cent from I93I to I935 equity entries decreased only 20 per cent. Another possible contributing cause may lie in the investigation directed by the Supreme Judicial Court into unprofessional practices by lawyers in accident cases which may have discouraged the bringing of some "nuisance" cases.

The ability of a court to clear its docket depends, in large degree, upon its trial capacity. The number of justices of the superior court has remained constant since r925. The court tries approximately 3,200 civil law cases a year, of which, roughly, 2,500 are jury cases and 700 are jury waived. The trial of civil law cases is only one phase of its work. It necessarily devotes much time to its equity and criminal calendars.

\section{Measures Adopted to Relieve Congestion in the Superior Court}

The effect of the greatly increased number of law entries occurring after 1927 upon the docket of the superior court has, of course, lengthened the time between entry and trial of jury cases. While in some of the sittings a jury case may be reached eighteen months after filing, in the larger sittings, and especially in Suffolk County in which the city of Boston is located and which receives nearly one half of the entries of civil cases in the Commonwealth, it takes between three and four years to have jury trial.

The delay in reaching trial has naturally caused much public discussion, and various efforts have been made to better the situation. Bills to require the payment of a jury fee as small as ten dollars have failed of enactment. Several steps recently taken, one by the legislature and the others by the superior court, seem to be helpful.

\section{Act Requiring All Motor Tort Cases to be Entered in District Courts}

In 1934, the legislature passed an act ${ }^{9}$ giving district courts exclusive original jurisdiction of actions of tort arising out of the operation of motor vehicles. The

${ }^{8}$ Mass. Jud. Council, Fifth Report, 1929, p. 7.

${ }^{2}$ Mass. Acts 1934 , c. 387 , commonly known as the Fielding Act. 
Constitution of Massachusetts gives parties a right to trial by jury. The voluntary entry of a case in a district court is an election to waive trial by jury. This act would undoubtedly be unconstitutional if it sought to compel a plaintiff to abandon his right to trial by jury. It therefore provides that after a plaintiff has entered his motor tort case in a district court he may, not less than two days nor more than four days after such entry, remove to the superior court. The defendant necessarily has always had the right to remove any case entered in a district court if he acts promptly. The effect of the act therefore is simply to require a motor tort case to be entered in a district court, leaving either party to the case full liberty to remove to the superior court.

Motor Tort Entries and Removals in District Courts and Boston Municipal Court October I, I934 to October I, I935

\begin{tabular}{|c|c|c|c|c|}
\hline & \multirow{2}{*}{$\begin{array}{c}\text { Motor Tort } \\
\text { Entries }\end{array}$} & \multicolumn{2}{|c|}{ Removals } & \multirow{3}{*}{$\begin{array}{l}\text { Total } \\
7,761^{*}\end{array}$} \\
\hline & & $\begin{array}{l}\text { By Plaintiff } \\
3,432\end{array}$ & $\begin{array}{l}\text { By Defendant } \\
4,277\end{array}$ & \\
\hline Boston Municipal Court, & & & & \\
\hline Oct. $x$-July $\mathrm{x}, \ldots \ldots$ & 7,303 & $x, 582$ & 396 & $x, 97^{8}$ \\
\hline oston Municipal Court, & & & & \\
\hline July I-Oct. I (Estimated). & 6,382 & 1,378 & 345 & 1,723 \\
\hline Total & $4 \mathrm{I}, 485$ & 6,392 & 5,018 & 11,462 \\
\hline
\end{tabular}

- 52 cases were removed by both parties.

It will be observed that 30,023 of the $4 \mathrm{r}, 485$ motor tort cases entered remained in the district courts and the Boston municipal court, and that $\mathrm{xr}, 462$ cases, constituting 27 per cent of the motor tort entries, were removed to the superior court. While the percentage of removals was practically the same for the district courts and the Boston municipal court, defendants removed 845 more cases from the district courts than did plaintiffs, whereas defendants were responsible for only $74 \mathrm{x}$ out of the $3,70 \mathrm{x}$ removals from the Boston municipal court.

That the act under discussion has resulted in relieving the superior court to some extent seems a reasonable guess, but as no statistics are available showing how many motor tort cases were entered in the superior court in any year prior to October $\mathbf{~}$, 1934, the date the act took effect, one can not be positive.

\section{References to Auditors}

Under the statutes of Massachusetts, ${ }^{10}$ the superior court may appoint one or more auditors to hear the parties and report to the court, the auditor's findings of fact being "prima facie evidence upon such matters only as are embraced in the order." After an auditor has made his report, either party may have a court trial, either with or without a jury, as one or the other may elect. At such trial, the auditor's report is read, but the parties may, after such reading, try the case de novo.

In I935, the justices of the superior court put into effect a plan for reference of motor tort cases to auditors. The plan provided that the several county bar asso-

${ }^{10}$ Mass. GEN. LAws (Tercent. ed. 1932) c. 221, $\$ 56$. 
ciations should submit a list of auditors from which the justice assigned to each county should select, subject to the right of the justice to add additional names. An important feature in the plan is the requirement that appointments as auditor shall be confined to lawyers who do not have motor tort cases and who will agree to refrain from taking such cases during their period of service as auditors.

During the period January 7 , I935 to January 4, I936, 3,807. motions for references to auditors were allowed; 420 cases were settled before the reference to the auditor was actually made; 5 or were settled after the rule issued, before report; and $\mathrm{x}, 089$ were settled after report. 2,I34 cases were finally disposed of after the motion for reference was allowed at a cost averaging only $\$ 32$ a case. ${ }^{10^{2}}$ Auditors are paid $\$ 5$ an hour for the actual time spent in hearings and in preparing their reports. ${ }^{10^{\mathrm{b}}} \mathrm{A}$ less favorable feature is the insistence by one party or the other on jury trial in 1,207 of the cases reported by auditors. There are indications, happily, that references of motor tort cases are meeting with growing favor on the part of the bar. It should, perhaps, be remarked that there was a feeling somewhat prevalent that the insurers, who are the real defendants as they pay the bill, would generally remove cases from the district courts and demand jury trial in the auditor cases. The statistics, however, clearly indicate that plaintiffs remove more cases than do the defendants, and demand jury trials after report by the auditor more frequently than do the deferidants.

A member of the Massachusetts bar has kindly given the writer the following interesting account illustrating the benefits which may be derived from trial by auditor:

${ }^{102}$ A more detailed analysis of cases referred to auditors for one county (Essex) from January II, r 935 through June 30 , 1936 , as follows:

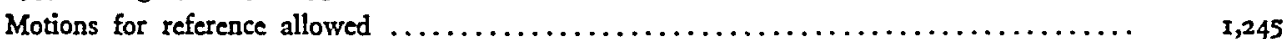

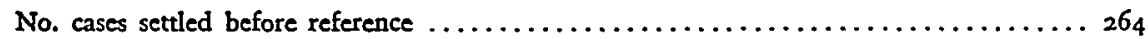

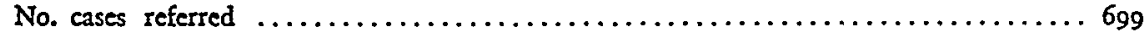

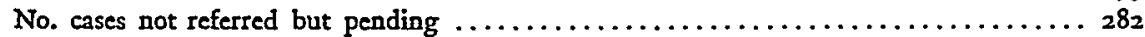

Disposition of cases referred

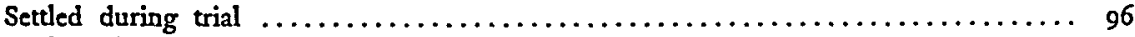

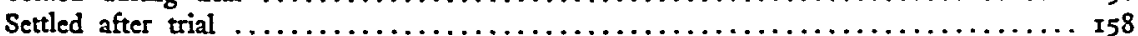

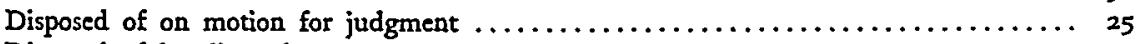

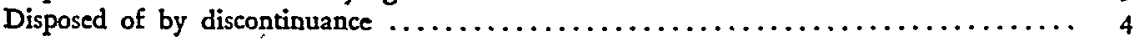

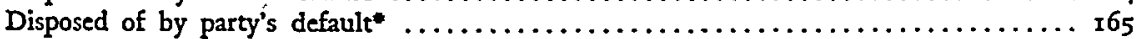

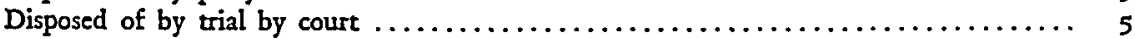

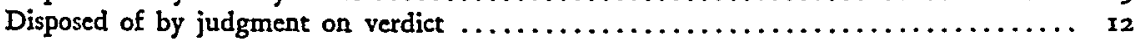

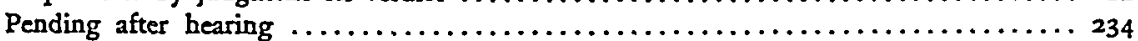

Total....................................................... 699

- It is provided by statute that if either party neglects to appear at the hearing, without just cause, or refuses to produce the testimony relied on by him, the auditor may close the hearing and recommend that judgment be entered for the adverse party. Judgment shall be entered accordingly at the first judgment day after ten days from the filing of the report, unless the court, for cause shown, otherwise orders. Mass. GEN. LAws, c. 22x, 558 .

Court trials have been demanded in $I 6_{4}$ cases after the filing of the auditor's report, in $4 \mathrm{I}$ cases by plaintiffs, in 40 , by defendants, and in 83 , by both parties. The foregoing table indicates that 729 cases have been actually finished on the docket, 264 having been settled before reference, 465 disposed of after reference. Auditor's fees totalled \$ro,412.13.

${ }^{10 b}$ The reference is always to a single auditor. 
As the result of a collision between a taxi-cab and a sedan one person was killed, three were seriously injured and several others suffered minor injuries. Nineteen law suits resulted in four different counties. The nineteen cases were consolidated and tried together before one auditor. Hearings ran for eight trial days, and before completion of the liability evidence all the cases were adjusted. If the cases had been tried before a jury they would in all probability have taken thirty trial days.

One of the great advantages of trial before the auditor was that, whenever two of the eleven attorneys engaged in the hearing came close to settling a case, the auditor was free to suspend the hearings for a few minutes or for a longer time while counsel conferred with clients. Thus the cases were settled one by one until all nineteen suits were disposed of. The county was spared the expense of even having the auditor file a detailed report. The auditor's bill to Suffolk County was $\$ 179.25$ and the entire cost to all four counties was $\$ 227.50$. The cost to the taxpayers of Massachusetts, if there had been jury trials of all the cases arising out of this one accident, might easily have reached from $\$ 10,000$ to $\$ 15,000$.

\section{Pre-trial Procedure in Suffolk County}

The superior court also adopted in 1935 a pre-trial procedure in Suffolk County based on the Detroit practice. Shortly before a case is to be reached for trial, counsel are notified to appear before the justice having charge of the pre-trial list, for a conference. Clients may appear and take part in the discussion, and frequently do. Plaintiff's counsel briefly states the essential facts on which he relies. Defendant's counsel does likewise. The court then discusses the possibility of a settlement. If efforts for settlement fail the justice endeavors in many cases to obtain waiver of jury trial, and ascertains whether the pleadings are in proper order. Requests for amendments must be presented at the pre-trial hearing. The justice also discusses with counsel the possibility of agreeing upon facts upon which there is no real dispute, to the end that the trial may be shortened and the parties saved the expense of unnecessary witnesses. Frequently the exact issues of fact to be tried are agreed upon. A blank form is filled out and signed by the justice. This form contains the name of the case, the names of the trial lawyers, the disposition of any request as to pleadings, the justice's opinion as to the chances of settlement, a statement of every fact agreed upon, and, frequently, a concise statement of the agreed issues to be tried.

The only other matter taken up at the pre-trial hearing is the date for the trial. The parties have been notified that they must find out in advance of the pre-trial call whether their witnesses are available. In order to save parties the expense of re-investigating their witnesses, the pre-trial call is held, ordinarily, not more than two weeks before the case is likely to be reached for trial. All requests for delay for causes then existing must be made at the pre-trial call. Once a case passes to the short list, continuances are granted rarely and only for causes arising after the pretrial call not due to the fault of the party desiring the continuance. 
The short list for trial is composed exclusively of cases already considered at the pre-trial call. Counsel receive two telephone notices from the list clerk-one the day before the case is actually held for trial, the other on the day the case is reached, a fifteen minute notice to appear in a particular session. ${ }^{11}$

The operation of the pre-trial procedure in its first ten months is indicated in the tables following:

Summary of Work in the Pre-trial Session of the Superior Court, Suffolk County September, 1935, to JuLy $x$, I936

Total number cases appearing in pre-trial lists................. 4,637

Pre-trial disposition of cases not marked for trial

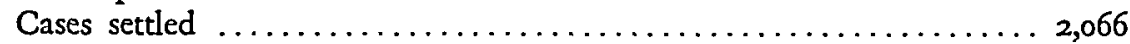

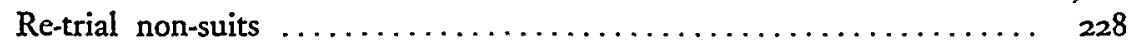

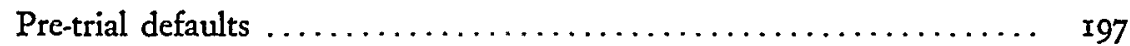

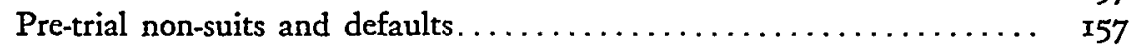

Pre-trial continuances $\ldots \ldots \ldots \ldots \ldots \ldots \ldots \ldots \ldots \ldots \ldots \ldots .427$

Cases pre-tried and marked for trial. ...................... $\frac{3,0 \ldots \ldots}{1,562}$

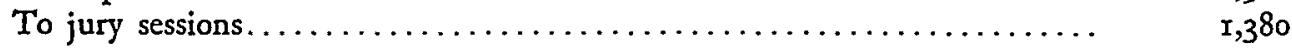

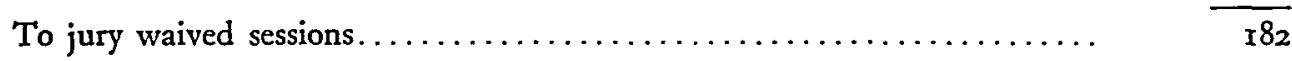

When the superior court adjourned on June 30,1936 it had reached for trial a case (No. 28447I) in which the writ was dated November 7, I932, whereas in the previous year the writ for the highest case reached (No. 26602I) was dated July 6, I93I. The significance of the gain of four months thus made can be better understood if it is realized that for many years the nearest date of writ actually reached for trial at the end of the court year had been progressively receding,

\section{Other Measures}

Reference should be made to three other steps taken in 1935 by the superior court. It put into effect in Suffolk County, where frequently as many as ten civil and criminal jury sessions are being held, a plan for a jury pool. Under this plan a talesman, instead of reporting to a particular sitting as formerly, reports to a central room from which he goes when his attendance is required as a juror and to which he returns when no longer needed in a sitting.

In January, I935, there were 279 jurors in actual attendance for four criminal and six civil sessions in Suffolk, and in February, 274. In November, 1935, after jury

1 The foregoing account of pre-trial procedure is taken from an informative article, Pre-Trial Procedure in Suffolk County, by Hon. Wilford D. Gray, the Justice of the Superior Court then in charge of the pre-trial call, appearing in the Bar Bulletin (Bar Ass'n of the City of Boston) No. 107 (Jan., 1936). "On many days since the new system went into effect," the learned Justice states in his article, "every case that has been notified to be ready for trial has actually had the opportunity to be tried on the first day, and it is the rare case that has been obliged to come more often than the second day. . . As nearly as we can make a comparison [with previous years] we appear to have disposed of several hundred, and perhaps as many as four hundred, more cases in the period of the opening of Court in September, 1935, to the end of the December sitting." 
pooling had gone into effect, there were 190 jurors in attendance, and in December, 193. It is announced that the annual saving in money resulting from jury pooling exceeds $\$ 75,000$ a year.

One serious difficulty confronting parties when a case was finally reached for trial was that it would frequently be found that counsel for one party or the other was then engaged in court somewhere else. To obviate this difficulty the superior court made an order effective September I, I935 throughout the Commonwealth, providing that "when an engagement of counsel is pleaded as a ground for postponement the court may postpone the trial of a case for not more than ten days, and upon the expiration of the postponement period there shall be no further postponement because of any engagement of counsel."

Another experiment tried by the court, with considerable success, is what is known as the " $\mathrm{A}$ " Session. Under this plan a named justice is selected to preside over a jury-waived session. When a jury case is about to be reached, the parties are allowed to waive jury trial and have the case tried in the jury-waived session. The reason for this " $A$ " Session is that lawyers are often willing to waive a jury if they know what judge will try the case who are not willing to do so without that knowledge.

\section{Concluding Remarks}

It will be obvious to the reader that not only are the justices of the superior court fully alive to the situation but also that they have adopted several ingenious methods for reducing congestion. Except for the statute requiring original entries of motor tort cases in a district court, all the measures above mentioned were adopted by the justices under their inherent rule-making power.

Sufficient time has not elapsed since the statute and rules of court just discussed became effective to warrant an opinion as to the maximum effect they will have in reducing congestion in the superior court. ${ }^{12} \mathrm{Mr}$. Justice Gray remarks in his article cited above, Pre-Trial Procedure in Suffolk County, "The average plaintiff's attorney is still wedded to the belief that success in such [personal injury] cases depends upon the jury trial." No doubt defendants' attorneys also frequently claim jury trial when the plaintiff does not. That the bar, as a whole, is jury-minded is indicated by the fact that on June 30 , I935 there were 50,473, cases awaiting jury trial as against 7,59r awaiting trial without jury. The impossibility of performing the task thrust upon the justices of the superior court may perhaps be made clear by the following supposition. If the chief justice and the thirty-one justices of the court should suspend all other work and devote themselves for the full court year of approximately 200 trial days to jury cases, and should each try one case a day, they would thus dispose by jury trial of only 6,400 cases. ${ }^{13}$

\footnotetext{
${ }^{12}$ One interesting feature about the various plans herein mentioned is that they do not work uniformly well throughout the Commonwealth. In some counties the bar seems to prefer trial by auditors, whereas in other counties the "A" session has the preference. Removals of motor tort cases also vary greatly, running from 15 per cent of the entries in some of the district courts to as high as 50 per cent in others.

${ }^{18}$ As a matter of fact, one trial may dispose of several cases. All cases arising out of the same accident are tried together, including cross actions. Thus there may be two or more cases by persons injured in
} 
The usual remedy suggested for relieving congestion is to increase the number of justices, and have more jury trials, but this method has never produced the result expected. Without entering upon a full discussion of the pros and cons, it is perhaps sufficient to say that there comes a time when the taxpayer rebels against increasing taxes. The only payment made by a plaintiff to the Commonwealth for a jury trial, which is estimated to cost the Commonwealth about $\$ 400$ a day, is his threedollar entry fee. The defendant, even though he claims a jury, when the plaintiff does not, pays exactly nothing. There is a limit to free service, and thus far the legislature, although strongly pressed, has resisted the temptation to increase the superior court bench. The Judicial Council stated in its annual report for I933, "In our opinion, the proposal to increase the number of judges [of the superior court] would be an expensive method of getting us nowhere, even if we had the courthouse space in which to use them."

It should be emphasized that the compulsory motor vehicle insurance act is not the sole cause of congestion. Even before it became effective in 1927 , the docket of the superior court was congested. The number of civil cases entered in the superior court for the year ending June 30, I910 was 10,868; for the year ending June 30, 1920, 15,638 ; and for the year ending June 30,1926 , the year immediately prior to the effective date of the compulsory insurance act, .23,223. It seems plain, therefore, that the compulsory insurance act merely accelerated the natural growth of entries, which the rapidly increasing number of motor cars after I 920 made inevitable.

It has been shown by experience extending over many years that the civil trial capacity of the superior court is approximately 3,200 jury and jury-waived cases a year; the number of entries per court year for the past ten years has always exceeded 22,000 cases, and has reached as high as 36, Ig0. Thus it would be natural to conclude that if 36,000 cases are entered in any one year and 3,200 are tried in a year the court would have to devote more than ten years to the trial of one year's 36,000 entries. Such is not the case. While the number of jury and jury-waived cases tried in the year ending June 30, 1935 was 3,I77 the number of law cases finally disposed of was 25,458; that is, for every case tried approximately seven disappeared from the docket without trial. The returns made by the clerks of court under the heading "Number finally disposed of" give no data as to the method of disposition. Doubtless a great many cases are settled, some to the complete satisfaction of the parties, and others because the plaintiffs, especially in accident cases, are unwilling or financially unable to wait three or four years for jury trial. Included in the cases finally disposed of are a certain number which are dismissed by rule of court because they have been marked inactive. In June of each year every case which has remained upon the docket for three years, without action, is marked inactive and at the end of the third year from the year in which it is marked inactive is automatically dismissed.

car No. I, brought against both the owner, and the operator, if other than the owner, of car No. 2, and the occupants of car No, 2 may, and usually do, bring actions against the owner and the operator of car No. I. 
Experience indicates that only about 20 per cent of the cases marked inactive are ever restored to the trial docket. During the court year ending June 30, 1935, 5,310 law cases were marked inactive-which is approximately the number marked inactive each year. Of those cases, 4,240 or 80 per cent of the total will presumably be dismissed in June, 1938. Those 4,240 cases represent a substantial financial outlay by either the plaintiffs or their lawyers-amounting at a guess to six dollars a case-or roughly $\$ 25,000$.

We seem to have evolved a system in this Commonwealth, which is doubtless substantially the same in all the more populous states, whereby actual trial of cases is relatively unimportant in its bearing upon congestion, since the parties either manage to compose their differences by settlement, or, in the case of plaintiffs, abandon their cases altogether, in seven cases out of every eight entered. Whether one likes it or not, the fact seems to be that the cost of jury trial, including overhead, estimated by the Judicial Council of Massachusetts ${ }^{14}$ at between $\$ 400$ and $\$ 500$ a day, makes it unlikely that the number of jury sittings will be substantially, if at all, increased in the immediate future. ${ }^{15}$

The several steps already taken in order to relieve congestion in the superior court are too recent to make it possible to draw sound conclusions as to their ultimate effect. If, however, the parties to motor tort litigation-in reality, that part of the bar which tries accident cases-should increasingly accept trial in district courts, or abide by the findings of the auditors in removed cases, it seems probable that the present congestion in the superior court will melt away. If, however, jury trials continue in large demand, the possibility always exists that motor tort cases will be bodily taken out of the courts and handed over to a commission. A proposal to that effect was considered and reported adversely by the Special Commission to Study Compulsory Motor Vehicle Liability Insurance and Related Matters, appointed under a resolve of the legislature. ${ }^{16}$

It is not the intention of the writer, however, to convey the impression that the present situation, however uncomfortable, is beyond hope. The discerning editor of the Journal of the American Judicature Society says of Massachusetts, "Here is a state in which so much investigation and planning is being done that it is hardly possible for a foreigner to keep abreast of affairs."17 An unforeseen result of the compulsory motor car insurance act, has been to focus public attention upon the courts, and, as clearly appears from the various measures above mentioned recently adopted by the superior court, to create in the judges a deeper sense of their own responsibility for the administration of justice.

\footnotetext{
14 Mass. Jud. Council Seventh Report, 1931, p. I3.

${ }^{15}$ Nothing said in this article is to be construed as a disparagement of the jury as an institution. The sole purpose of the writer is to set forth statistically as far as possible, and entirely dispassionately in any event, the cold facts with respect to the possibility of obtaining jury trial in Massachusetts.

${ }^{10}$ Sen. Rep. 280 (1930), reprinted in (1930) 15 MAss. L. Q., No. 3.

${ }^{17}$ (Aug. I936) 20 J. AM. JUD. Soc. 47.
} 